Ks. Ryszard Kilanowicz

Ius Matrimoniale

$30(2019) \mathrm{nr} 2$

DOI:10.21697/im.2019.30.2.05

Wydział Teologiczny UPJP 2 w Krakowie

\title{
Obrzędy sakramentu małżeństwa w ujęciu wymogów Kodeksu Prawa Kanonicznego z 1983 roku
}

Treść: Wstęp. 1. Działanie znaków sakramentalnych. 2. Obowiązujący obrzęd małżeństwa. 3. Obrzędy jak znak sprawczy sakramentu. 4. Skutki sakramentalne wyrażone w obrzędach sakramentu małżeństwa.

5. Zakończenie.

\section{Wstęp}

Obrzędy liturgiczne Kościoła Rzymskokatolickiego są mocno osadzone w życiu Kościoła. Nie są przypadkowym zespołem czynności i słów, które dokonuje szafarz sakramentu wobec wierzącego, ale są jasno określonymi znakami, których kodowanie przenosi człowieka w inną rzeczywistość. Kościół w swoich działaniach liturgicznych korzysta i posługuje się elementami naturalnymi (np.: chleb, wino, światło, ogień, woda, dym, oliwa, sól, popiół). Używane one były w kulturach i religiach przedchrześcijańskich, ponieważ same w sobie są nośnikami pewnej rzeczywistości, która jest głębsza od samej tylko powierzchownej i materialnej otoczki.

W obrzędach sakramentalnych nie chodzi zatem o materialny wydźwięk znaków i czynności (np. woda obmywa ciało z brudu i odświeża), ale o takie odczytanie znaku, który w swej prostocie staje się narzędziem uwielbienia i oddania czci Bogu (woda chrzcielna obmywa z grzechu, tym samym daje nowe życie i nową jakość człowiekowi). Dzięki tym znakom w liturgii, wierzący wykonują swoją 
podstawową funkcję kapłańską w stosunku do całego stworzenia. Posoborowa Konstytucja o liturgii tak to ujmuje: przez znaki widzialne wyraża się, i w sposób właściwy poszczególnym znakom urzeczywistnia się uświęcenie człowieka, a Bóg otrzymuje całkowity kult publiczny (KL 7).

W sprawowaniu obrzędów liturgicznych ważne jest także stosowanie znaków umownych, co do których rozumienie jest znane tym, którzy ich wykładnię poznają oraz mieszanych, które zawierają elementy naturalne jak i umowne.

W przypadku sprawowania sakramentów, obrzędy są jasno określone przez prawo Kościelne, które przez wieki było formowane i kształtowane życiem a więc i liturgią Kościoła. Liturgia jest podstawowym przejawem życia Kościoła. Obrzędy wpływają od wieków na kształt prawa, wynikają bowiem z kultury, w której dana społeczność rozwija swoją tożsamość, a tym mówi i informuje o swojej naturze.

\section{Działanie znaków sakramentalnych.}

Każdorazowe uczestnictwo w liturgii Kościoła przenosi nas w świat znaków - które, jak naucza Kościół - z ustanowienia Bożego są nośnikami konkretnych łask. Jednakże, przy wielkiej laicyzacji społeczeństwa trzeba być ostrożnym, aby nie ulec traktowaniu tego co „robi” Kościół w ujęciu magicznym. Spojrzenie z wiarą na sakramenty, wszystkie razem czy każdy z osobna, winno prowadzić tylko do jednego wniosku. Tym wnioskiem jest rozumienie sakramentu jako spotkania Boga z człowiekiem. Wtedy przestrzeń znaków liturgicznych staje się w konkretnych obrzędach miejscem teologicznego poznania Boga ${ }^{1}$. W rzeczywistości widzialnej, materialnej przez to, co widzimy i słyszymy, a więc słowo, czyn i gest, rozgrywa się rzeczywistość niewidzialna, duchowa, w której żywy Bóg wchodzi z konkretną łaską w życie człowieka, a co za tym idzie, z konkretnymi skutkami, które dotykają uczestnika danego wydarzenia i zgromadzenia liturgicznego.

1 Por. B. NAdolski, Liturgika, t. III, Sakramenty, sakramentalia i błogosławieństwa, Pallottinum, Poznań 1992, s. 7. 
Najpierw trzeba nam więc wejść w świat liturgii i rozumienia obrzędowości katolickiej, aby w pełni zobaczyć i zrozumieć, że liturgia to nie tylko suchy rytualizm, ale żywa rzeczywistość uobecniająca Boga tu i teraz w historii świata.

Doświadczanie żywego Boga, dokonuje się więc w świcie znaków, które teologia określa mianem symboli. Termin ten zaczerpnięty z nauk humanistycznych odnosi nas do starożytnego - greckiego rozumienia. Symbolon z gr. znak rozpoznawczy, gdzie rzeczywistość bezpośrednia, fizyczna, literalna odsyła nas do sensu ukrytego, przenośnego nadprzyrodzonego ${ }^{2}$. Takie rozumienie ukazuje, że sens tego co widzimy jest głębszy i niesie ze sobą więcej treści, niż sam znak, który jest dostrzegalny. Tego określenia używano często na określenie znaku rozpoznawczego pomiędzy kupcami, politykami, a nawet i wojskowymi, którzy identyfikowali się przełamaną tabliczką, monetą. Ksiądz Nadolski ${ }^{3}$ w swoich opracowaniach pisze, że podążanie i szukanie przez jedną część drugiej jest idealne w rozumieniu sakramentu jako łączenia się człowieka z Jezusem, w którym tylko stworzenie może doznać pełni tego, czego poszukuje w codzienności ${ }^{4}$.

Już od pierwszych wieków chrześcijaństwa, u podstaw uczestnictwa w obrzędach, było postrzeganie liturgii jako historycznej ciągłości działania Boga w świecie oraz życiu wspólnoty Kościoła, jako naturalnego miejsca, gdzie Bóg realnie przebywa, działa i obdarza łaskami ${ }^{5}$. Dopełnienia takiego rozumienia rzeczy dokonuje św. Augustyn ${ }^{6}$. Określając rzeczywistość spotkania Boga z człowiekiem w obrzędowości, zaczyna stosować termin sacramentum łac. widzialny znak. Jego rozumienie znaku staje się dla Kościoła fundamentalnym rozumieniem znaków sakramentalnych. Znak staje się słowem widzialnym. To Kościół jest tym, który posiada łaskę sakramentalną.

2 Symbolw: Encyklopedia chrześcijaństwa, red. H. Witczyk, Jedność, Kielce 2000, s. 690 .

3 Bogusław Nadolski (1933-2018) - chrystusowiec, profesor nauk teologicznych, specjalista w zakresie liturgiki.

4 Por. Nadolski B., Liturgika, t. III, Sakramenty..., dz. cyt., s. 8.

5 Por. B. Testa, Sakramenty Kościoła, Pallottinum, Poznań 1998, s. 26.

6 Święty Augustyn z Hippony, (354-430) - filozof, teolog, ojciec i doktor Kościoła, 
Kościół wykonując gest i wypowiadając słowo, przywołuje łaskę przypisaną, daną przez Boga. Nie jest to wspomnienie, nie jest to teatr, czy zaklinanie rzeczywistości ale konkretne działanie Boga ${ }^{7}$.

Takie rozumienie przypieczętowali scholastyczni myśliciele XII wieku min. św. Tomasz z Akwinu ${ }^{8}$, Aleksander z Hales ${ }^{9}$, Bonawentura $^{10}$, Jan Duns Szkot ${ }^{11}$, którzy doprecyzowali zasadę działania sakramentów zawartą w terminie łacińskiej sekwencji: ex opere operato $^{12}$. Głównym działającym, gwarantem skuteczności i sprawczości sakramentu jest nie kto inny, a sam Jezus Chrystus. Tam gdzie dokonano sakramentalnych znaków, w imieniu i zgodnie z intencjami Kościoła, tam zadziałał sam Jezus Chrystus mocą Swojej zbawczej ofiary $^{13}$.

\section{Obowiązujący obrzęd małżeństwa.}

Powyższe spojrzenie daje nam właściwe narzędzie na badanie i analizę obrzędów sakramentu małżeństwa. Obrzędy sakramentu małżeństwa na przestrzeni dziejów Kościoła ulegały przemianom. Zawsze jednak dotyczyły mężczyzny i kobiety, jako materii sakramentu, która ustanowiona mocą Bożą jest niezmienna, wszystko zaś inne - gesty i teksty, jeśli nie są bezpośrednio dane przez Boga (konsekracja, włożenie rąk) decyzją Kościoła mogą ulec zmianie. Pierwsze opisy i informacje jak wyglądały obrzędy sakramentu małżeństwa

\footnotetext{
7 Por. B. Testa, Sakramenty Kościoła, dz. cyt., s. 28-29.

8 Święty Tomasz z Akwinu (1225-1274) - filozof scholastyczny, teolog, dominikanin, doktor Kościoła, jednym z najwybitniejszych myślicieli w dziejach chrześcijaństwa.

9 Aleksander z Hales (ok. 1183-1245) - teolog i filozof średniowieczny, franciszkanin jeden z pierwszych komentatorów Arystotelesa na Zachodzie.

10 Święty Bonawentura (ok. 1217-1274) - biskup i kardynał, teolog, filozof scholastyk, doktor Kościoła, siódmy generał franciszkanów.

11 Błogosławiony Jan Duns Szkot (1266-1308) - filozof i teolog, franciszkanin.

12 ex opere operato - łac.: sakrament dokonuje się na podstawie wykonania danej czynności, określonego znaku i obrzędów (zespołu znaków), człowiek zostaje obdarowany łaską sakramentalną z pominięciem jego wewnętrznej predyspozycji

13 Por. B. Nadolski, Liturgika, t. III, Sakramenty..., dz. cyt., s. 11.
} 
zawdzięczamy Tertulianowi ${ }^{14}$. Z jego opisów wiemy, że obrzędy te zawierały takie elementy jak przysięga, pocałunek i nałożenie pierścionka (Tertulian, Apologia 6, 4).

Obrzędy, które obowiązują dziś w Kościele zostały zatwierdzone w 1969 r. Na dzień dzisiejszy korzystamy z III wydania tych obrzędów ubogaconych i uaktualnionych przez zmiany wynikające z Kodeksu Prawa Kanonicznego ogłoszonego 1983r. Wprowadzenie teologiczne i pastoralne, które znajduje się na początku księgi Obrzędy Sakramentu Małżństwa dostosowane do zwyczajów diecezji Polskich w swoich punktach odnosi się bezpośrednio do kanonów Kodeksu Prawa Kanonicznego (KPK) i kształtując całość obrzędu z uwzględnieniem zwyczajów lokalnych (KPK 1120) jako praktyczne wykonanie prawa. Księga IV Kodeksu Prawa Kanonicznego, Część I Sakramenty, Tytuł VII - małżeństwo, w kanonach 1055-1165 stanowi wykładnię prawną co do zawierania sakramentalnych związków małżeńskich. Dlatego obrzędy, które Kościół Katolicki uznaje jako sprawcze dla sakramentu małżeństwa muszą być jasno określone (KPK 1119).

\section{Obrzędy jak znak sprawczy sakramentu.}

Sam Jezus Chrystus w swoim nauczaniu nawiązuje do planu stwórczego zawartego w Księdze Rodzaju i stwierdza, że małżeństwo jest jednością dwóch osób i jest nierozerwalne (Mt 19, 1-9). Odtąd dwoje małżonków są poprzez wolny swój wybór „jednym ciałem”. Jezus nie tylko widzi, że małżeństwo ma odzwierciedlać doskonałość pierwotną. On sam kładzie nowy fundament pod tę instytucję, nadając jej tym samym znaczenie religijne w Królestwie Bożym. Na mocy nowego przymierza, które zawarł we krwi własnej (Mt 26, 28), staje się On sam Oblubieńcem Kościoła. Kanon 1055 KPK określa tym samym status małżeństwa jako sakrament, a co za tym idzie zawieranie

\footnotetext{
14 Tertulian (pomiędzy 150 a 160-240) - łaciński teolog z Afryki Północnej, nawrócony na chrześcijaństwo w 190 roku, stał się jego najgorliwszym w owym czasie apologetą (obrońcą). Nauczanie Tertuliana jest cennym źródłem dla teologii, szczególnie dla teologii dogmatycznej.
} 
związku małżeńskiego domaga się obrzędu, który by tę konkretną łaskę sprawiał i konstytuował w świecie liturgii Kościoła.

Nauka o sakramentach domaga się również, aby małżeństwo zawierane było w czasie Mszy świętej, określone są również konkretne okoliczności, które przemawiaj za inną formą ${ }^{15}$. Owocność sakramentu małżeństwa jest uzależniana i związana z przystąpieniem do sakramentu pokuty i pojednania oraz przyjęciem Jezusa Eucharystycznego (KPK $1065 \$ 2$ ). Eucharystia jest znakiem Nowego Przymierza. W nim Jezus zjednoczył się na wieki z Kościołem, dlatego nie ma co do tego wątpliwości, aby małżonkowie pieczętowali swoje wyrażenie zgody na wzajemne oddanie się sobie, jednocząc się z Ofiarą Jezusa, która się dokonuje w Ofierze Eucharystycznej (Katechizm Kościoła Katolickiego (KKK) 1621). Niektórzy badacze twierdzą, że już Ojcowie Kościoła praktykowali zawarcie małżeństwa wraz ze sprawowaniem Eucharystii, ale te głosy są podzielone ${ }^{16}$. Kościół również określa formy zawierania związku małżeńskiego z osobą ochrzczoną niekatolicką bądź osobą będącą niechrześcijaninem (mówi o tym rozdział KPK zatytułowany: Małżenstwa mieszane, KPK 1124-1129), dlatego sakrament małżeństwa może być sprawowany ze słusznym uzasadnieniem również poza Mszą świętą ${ }^{17}$. Takie sytuacje również są przewidziane w Obrzędzie.

Kościół naucza, że przymiotami małżeństwa są jedność i nierozerwalność (KPK 1056) dlatego według obrzędu, do nupturienta (łac. nupturiens - w prawie rzymskim, stąd również w prawie kanonicznym oraz rodzinnym, określenie osoby mającej zawrzeć związek małżeński) kieruje się pytania przed wyrażeniem zgody małżeńskiej: Czy chcecie wytrwać $w$ tym zwiazku w zdrowiu i w chorobie, $w$ dobrej $i$ złej doli, aż do końca życia? ${ }^{18}$. Kościół posługuje się szczególnym narzędziem, które każdy człowiek posiada. Jest nim słowo. To słowem

\footnotetext{
15 Obrzędy Sakramentu Małżeństwa dostosowane do zwyczajów diecezji Polskich, Księgarnia św. Jacka, Katowice 2010, 29.

16 Por. B. Nadolski, Liturgika, t. III, Sakramenty..., dz. cyt., s. 195-196.

17 Obrzędy Sakramentu Małżeństwa ..., dz. cyt., 34; 36.

18 Tamże, 60.
} 
Bóg stwarzał świat. Jego słowo ma moc sprawczą i jest niezmienne. Na człowieku spoczywa odpowiedzialność, aby jego słowo było prawdziwym wyrażaniem myśli i tego co doświadcza. Sakrament dokonuje się w relacji z Bogiem, dlatego interakcja - odpowiedź człowieka na słowo wypowiadane przez Kościół jest istotą obrzędowości.

Zawieranie związku małżeńskiego dokonuje się przez wyrażenie woli (KPK 1057). Jan Chryzostom ${ }^{19}$ pisał tak: O małżeństwie nie decyduje akt płciowy, ale wola ${ }^{20}$. Akt płciowy jest dopełnieniem zgody już wyrażonej (KPK 1061). Karol Wielki ${ }^{21}$ domagał się aby na podległych mu terenach frankońskich biskup sprawdzał, czy nie zachodzi w zgłaszanym małżeństwie przeszkoda pokrewieństwa. Są to pierwsze wzmianki o pewnej formie "pomocy lub współpracy” tronu cesarskiego z władzą kościelną co do małżeństwa. Natomiast w X w. Kościół posiadał już całkowitą kompetencję w sprawach małżeńskich chrześcijan i dążył do możliwie pewnego określenia ważności zawartego związku. Stąd też Kościół teraz pyta narzeczonych o wolną decyzję na małżeństwo oraz szczerą wolę zawarcia związku matrymonialnego. W XII-XIII w. pojawiają się już w rytuałach gallikańskich określone formuły takiego „pytania o zgodę"22.

Kościół pyta kandydatów najpierw o dobrowolność i brak jakiegokolwiek nacisku bądź presji czy przymusu w podjęciu decyzji co do wstąpienia w związek małżeński: N. i N., czy chcecie dobrowolnie i bez żadnego przymusu zawrzeć związek matżeński? ${ }^{23}$ Jakikolwiek przymus, lub też okoliczność wywierająca presję a tym samym ograniczająca dobrowolność wyrażającego zgodę jest przeszkodą zrywającą

19 Święty Jan Chryzostom (Jan Złotousty) (ur. przed 350-407) - biskup Konstantynopola, pisarz chrześcijański, doktor Kościoła, uznawany za największego kaznodzieję kościoła Wschodu.

20 Por. B. Testa, Sakramenty... s. 355.

21 Błogosławiony Karol I Wielki (742 lub 747-814) - król Franków i Longobardów, cesarz rzymski od 25 grudnia 800. Wnuk Karola Młota, syn Pepina Krótkiego z dynastii Karolingów. Zbudował pierwsze europejskie imperium od czasów upadku cesarstwa zachodniorzysmkiego w 476r.

22 Por. B. Nadolski, Liturgika, t. III, Sakramenty..., dz. cyt., s. 195-196.

23 Tamże. 
małżeństwo (KPK 1089; 1098; 1103). Pomiędzy tymi pytaniami, wyrażeniem zgody, przywołuje się Ducha Świętego ${ }^{24}$, który jest sprawcą każdego sakramentu i to on nadaje znakom mocy uświęcania. Zgoda, która jest fundamentem zawarcia sakramentu małżeństwa dokonuje się przez deklarację: Ja, N., biorę ciebie, N., za żonę/męża i ślubuję ci miłość, wierność i uczciwość małżeńska oraz że cię nie opuszczę aż do śmierci. Tak mi dopomóż, Panie Boże wszechmogacy, w Trójcy Jedyny, $i$ wszyscy Święci ${ }^{25}$. Ze słusznej racji (zdrowotna), zgodę można wyrazić również odpowiadając na pytanie: N., czy chcesz wziąć $N$. za żonęl męża i ślubować jej/mu miłość, wierność i uczciwość małżeńska oraz $\dot{z}$ e jej/go nie opuścisz aż do śmierci ${ }^{26}$ Zgoda jest tak istotna, że obrzęd zakłada nawet niewerbalną formę jej wyrażenia wobec kapłana i świadków: Jeżeli narzeczeni nie moga mówić, podpisuja formułę wobec kapłana i świadków lub innymi znakami wyrażają zgodę na mał$\dot{z} e n ́ s t w o^{27}$. KPK 1101 dopuszcza takie wyrażenie woli nupturientów, $\mathrm{z}$ naciskiem, że musi być na tyle zrozumiała, aby świadkowie odczytali ją jednoznacznie. Kościół Rzymskokatolicki uważa, że to małżonkowie sami sobie nawzajem udzielają sakramentu małżeństwa wyrażając zgodę wobec Kościoła (KKK 1623). Pieczętowaniem i potwierdzeniem zgody wstąpienia w sakramentalny związek małżeński przez nupturientów jest błogosławieństwo, które wykonuje kapłan nad nowymi małżonkami tuż po zawarciu małżeństwa. Towarzyszy temu deklaracja powołująca się na autorytet Kościoła, kapłan wypowiada słowa: „Co Bóg złączył, człowiek niech nie rozdziela”. Małżeństwo przez was zawarte ja powaga Kościoła katolickiego potwierdzam i błogosławię w imię Ojca i Syna, i Ducha Świętego ${ }^{28}$. Kapłan mocą sakramentalnego kapłaństwa powierzonego przez Chrystusa w imieniu Kościoła błogosławi i potwierdza zawarcie związku małżeńskiego. Obrzęd w tym miejscu powołuje się na pierwotny znak, który był obecny podczas

\footnotetext{
24 Por. Obrzędy Sakramentu Małżeństwa..., dz. cyt., 9.

25 Tamże 63.

26 Tamże 64-65.

27 Tamże 66.

28 Tamże 67.
} 
zaślubin u chrześcijan a mianowicie wiedza a z czasem i obecność biskupa. U Ignacego Antiocheńskiego ${ }^{29}$ w piśmie Do Polikarpa ${ }^{30}$ czytamy: Godzi się zaś, aby mężczyźni, którzy się żenia i kobiety, które wychodza za mą̇, łaczyli się $z$ wiedza biskupa, aby małżństwo było zawierane zgodnie z myśla Bożą, a nie zgodnie z pożąliwościami. Wszystko niech dzieje się na chwałę Bożą ${ }^{31}$. Natomiast o obecności kapłana i liturgii z tym związanej pisze Tertulian ${ }^{32}$.

Wyrażeniu zgody towarzyszy obrzęd wyjaśniający - podanie sobie prawych dłoni przez zawierających małżeństwo - zwyczaj znany już od pierwszych wieków chrześcijaństwa, zapewne obecny w wielu ówczesnych jak i wcześniejszych kulturach ${ }^{33}$. Przewiązanie dłoni stułą pojawia się około wieku XV w Polsce. Obrzęd ten jest opisany w pontyfikale biskupa krakowskiego. Mocą kapłaństwa chrystusowego dwoje ludzi, kobieta i mężczyzna są związani do końca życia. Jest to zewnętrzny znak węzła małżeńskiego, który od tego momentu dotyka dwojga ludzi. Ręka jest dla człowieka organem najważniejszym. To rękami człowiek wykonuje prace, pomaga, błogosławi ale i krzywdzi. W Biblii ręce oznaczają działanie i obdarowywanie. Prawa ręka jest odczytywana w wielu kulturach, nie tylko europejskich, jako ta właściwa i ta pierwsza, po której działaniu oczekuje się właściwych rezultatów i szczęścia ${ }^{34}$.

Drugim obrzędem wyjaśniającym jest nałożenie obrączek. Przywołany już Tertulian podaje, że nałożenie pierścionka było nie

\footnotetext{
29 Święty Ignacy Antiocheński (ok. 30-ok. 107) - biskup Antiochii, męczennik chrześcijański, jeden z pierwszych Ojców Kościoła.

30 Święty Polikarp ze Smyrny (pomiędzy 69 a 82-156) - biskup Smyrny, zaliczany do ojców apostolskich - najstarszych pisarzy wczesnochrześcijańskich, którzy tworzyli bezpośrednio po czasach apostolskich i powoływali się na autorytet apostołów szczególnie świętego Jana.

31 Cyt. Pierwsi świadkowie. Pisma Ojców Apostolskich, (Biblioteka Ojców Kościoła. T. 10). Wydawnictwo M, Kraków 1998, s. 141.

32 Por. B. Nadolski, Liturgika, t. III, Sakramenty..., dz. cyt., s. 194.

33 Por. B. Nadolski, Liturgika, t. III, Sakramenty..., dz. cyt., s. 195.

34 Ręka, prawo i lewo w: Słownik obrazów i symboli biblijnych, M. Lurker, tł. K. Romaniuk, Pallottinum, Poznań 1989, s. 186, 197-198.
} 
religijnym obrzędem, a znakiem zaręczyn, które odbywały się jakiś czas przed zawarciem małżeństwa. Podczas tego wydarzenia, narzeczony wkładał pierścionek zaręczynowy - pierwotnie żelazny, później złoty- na czwarty palec lewej ręki narzeczonej. (Tertulian, Apologia 6,4). Pisma papieża Mikołaja I ${ }^{35}$ do Bułgarów z IX wieku, tłumaczą ten gest jako poręczenie i poświadczenie chęci wstąpienia w związek małżeński wyrażony, nałożeniem pierścienia przez mężczyznę na palec kobiety, względem, której ma poważne plany. Z czasem „pierścień zaręczynowy” stał się teraz „pierścieniem ślubnym” i symbolizuje wierność małżeńską oraz nierozerwalność związku. Stanowi znak zawartego małżeństwa. Kapłan więc nie tylko błogosławi go, ale podaje narzeczonemu, by on nałożył go narzeczonej lub nawet kapłan wraz z narzeczonym wkłada go na palec narzeczonej (jeszcze po Soborze Trydenckim ${ }^{36}$ mówi się o jednym pierścionku ${ }^{37}$ ). Ceremonia ta odbywa się pod okiem kapłana - celebransa, który stoi na straży poprawności tego znaku, gdyż oznacza dopełnienie zgody. (Już w XI w. istniał zwyczaj nakładania pierścienia ślubnego na palec prawej ręki narzeczonej) ${ }^{38}$. Symbolika pierścienia opiera się na jego okrągłym kształcie. Na linii, która tworzy koło wracając do swego początku, wszystkie punkty są jednakowo oddalone od środka. W ten sposób uzyskujemy obraz całości zamkniętej w sobie, czegoś co jest bezgraniczne i wieczne. U starożytnych rzymian, jak i dziś pierścień oznacza połączenie, pomiędzy dwojgiem ludzi (czego znakiem są dziś dwie obrączki). Po dziś oznacza wzajemne przywiązanie ${ }^{39}$.

\footnotetext{
35 Święty Mikołaj I Wielki (ok. 820-867), papież w latach 858 do 867.

36 Sobór Trydencki - sobór powszechny Kościoła katolickiego, który miał miejsce w latach 1545-1563. Był odpowiedzią na narastającą potrzebę reform w Kościele katolickim. Jest uznawany za początek kontrreformacji.

37 Według obrzędu zawartego w Rituale Romanum z 1614 r. - zbiorze obrzędów Kościoła Rzymskokatolickiego po soborze trydenckim.

38 Por. B. Mokrzycki, Kościół w świętości. Akademia Teologii Katolickiej, Warszawa 1984, s. 293.

39 Pierścień, okrąg w: Słownik obrazów i symboli biblijnych, dz. cyt., , s. 153; 175.
} 


\section{Skutki sakramentalne wyrażone w obrzędach sakramentu małżeństwa}

Skutkiem małżeństwa ważnie zawartego jest węzeł małżeński (KPK 1134). Łączy on kobietę i mężczyznę na wyłączność, do śmierci jednego $\mathrm{z}$ nich. Ponadto węzeł ten wzmacnia i uświęca relację małżonków. Jan Paweł II w Familiaris consortio pisze tak: że pierwszym i bezpośrednim skutkiem małżeństwa nie jest sama łaska nadprzyrodzona, ale chrześcijańska więź małżeńska, komunia dwojga typowo chrześcijańska, ponieważ przedstawia tajemnicę Wcielenia Chrystusa i tajemnicę Jego Przymierza (FC 13). Węzeł małżeński został więc ustanowiony przez samego Boga, tak, że zawarte i dopełnione małżeństwo osób ochrzczonych nie może być nigdy rozwiązane. Węzeł wynikający z wolnego, ludzkiego aktu małżonków i z dopełnienia małżeństwa jest odtąd rzeczywistością nieodwołalną i daje początek przymierzu zagwarantowanemu wiernością Boga. Kościół nie ma takiej władzy i nie uznaje, by ktokolwiek mógł wypowiadać się przeciw postanowieniu mądrości Bożej. Jedyną okolicznością rozwiązującą węzeł małżeński ważnie zawarty jest śmierć.

W tym samym punkcie jest mowa o samej łasce dawanej przez Boga. Jest to drugi skutek małżeństwa: Małżonkowie sq zatem stałym przypomnieniem dla Kościoła tego, co dokonało się na Krzyżu; wzajemnie dla siebie i dla dzieci sa świadkami zbawienia, którego uczestnikami stali się poprzez sakrament. Małżenstwo, podobnie jak każdy sakrament, jest pamiątka, uobecnieniem i proroctwem tego zbawczego dzieła: "Jako pamiątka, sakrament daje im łaskę i zadanie upamiętniania wielkich dzieł Bożych i świadczenia o nich wobec swych dzieci; jako uobecnienie, daje im łaskę i zadanie wprowadzania wżycie, wzajemnie wobec siebie i wobec dzieci, wymogów miłości, która przebacza i darzy odkupieniem; jako proroctwo, daje im łaskę i zadanie życia i świadczenia o nadziei przyszłego spotkania z Chrystusem" (FC 13). Łaska dana w sakramencie mówi sama przez się. Sakrament to dar Boga, uświecający tych, którzy chcą z nim współpracować, dlatego tak ważna jest predyspozycja i stan wnętrza człowieka (KPK $1065 \$ 2)$. Dar ten jest o tyle ważny, że domaga się aktu miłości, w którym jest 
podawany dalej na innych ludzi. Najpierw na dzieci a potem przez relacje na bliźnich. Łaska wypływa z samej natury sakramentu. Jest darem dla małżonków, który umacnia i cementuje i uświęca miłość wzajemną.

KPK 1136-1140 mówi o dzieciach - rodzinie, jako skutku małżeństwa. Małżeństwo jako sakrament, a nie instytucja wprowadza mężczyznę i kobietę w określony stan życia. Ojcowie Kościoła częściej mówili o stanie niż o samej zgodzie małżeńskiej. W kontekście kolejnego skutku, jakim jest rodzina, święty Jan Paweł II pisze tak: Podstawowym zadaniem rodziny jest służba życiu, urzeczywistnianie $w$ ciagu dziejów pierwotnego błogosławieństwa Stwórcy: przekazywania - poprzez rodzenie - obrazu Bożego z człowieka na człowieka. Płodność jest owocem i znakiem miłości małżenskiej, żywym świadectwem pełnego wzajemnego oddawania się małżonków: „... prawdziwy szacunek dla miłości małżeńskiej i cały sens życia rodzinnego zmierzaja do tego, żeby małżonkowie, nie zapoznając pozostałych celów mał̇̇eństwa, skłonni byli mężnie współdziałać z miłościa Stwórcy i Zbawiciela, który przez nich wciąż powiększa i wzbogaca swoja rodzinę" (FC 28). Małżeństwo to otwieranie się na Boga, który dzieli się swoją mocą stwórczą z rodzicami. Świadomość bycia rodzicami winna być nieodzownym elementem decydowania się na rodzinę i małżeństwo, dlatego też tuż przed wyrażeniem zgody małżeńskiej, obrzęd zaleca skierować pytanie do nupturientów: Czy chcecie z miłością przyjać i po katolicku wychować potomstwo, którym was Bóg obdarzy? ${ }^{40}$

Pytania stawiane tuż przed zawarciem małżeństwa mają na celu ukazanie najważniejszych aspektów, które muszą wybrzmieć i odcisnąć się w świadomości narzeczonych. Odpowiedzi na pytania, oraz wyrażenie zgody małżeńskiej, które zakłada obrzęd, nupturienci wypowiadają publicznie przed Bogiem, wobec świadków, kapłana, a także przed Kościołem, który tworzą uczestnicy zgromadzenia liturgicznego. Przez to, obrzęd, z wszystkich zgromadzonych na świętowanie zawarcia związku małżeńskiego czyni świadkami zgody małżeńskiej.

40 Obrzędy Sakramentu Małżeństwa ..., dz. cyt., s. 60. 
KPK zakłada i uznaje katechizowanie, oraz przepowiadanie (homilia) jako podstawowy nośnik i formę uświadamiania wiernych Kościoła w rozumieniu stanu małżeńskiego. Nacisk położony jest również na ars celebrandi liturgii Mszy świętej z sakramentem małżeństwa (KPK 1063). Wprowadzenie teologiczne i pastoralne dookreśla dobitnie przestrzenie zaangażowania wiernych i nupturientów: wybór czytania z Pisma Świętego, formę wyrażenia zgody, formularz błogosławieństwa obrączek, błogosławieństwo ślubne, intencje modlitwy powszechnej, śpiewy ${ }^{41}$. Jest to zadanie duszpastersko-pastoralne, które ma nie tylko pouczać ale przez sposób sprawowania i świętowania wydarzenia zawarcia związku małżeńskiego, przenosić wszystkich uczestników liturgii w przestrzeń nadprzyrodzonej działalności Bożej łaski. Na tym ma polegać liturgia - przez swoją prostotę, harmonię i piękno, które wynikają ze świadomości tych, którzy biorą w niej czynny udział, odzwierciedla liturgię niebieską, której doświadczymy po zakończeniu ziemskiego pielgrzymowania.

Zależność obrzędowości od prawa koreluje ze sobą. Nie jest tak, że jedno podlega drugiemu. Ale jedno zakłada drugie i wypływa jedno $\mathrm{z}$ drugiego. Niektóre elementy jak zgoda były fundamentalne w obrzędowości, więc prawo określiło jej nadrzędną rolę. Natomiast forma obrzędów jest kształtowana przez prawo obowiązujące w danym czasie cały Kościół. Ta zależność dobrze pokazuje, jak Bóg w każdym momencie dziejów pragnie wychodzić do człowieka, mówić przez znaki święte i obdarzać stworzenie, a zwłaszcza człowieka swoją łaską i miłością.

\section{Zakończenie}

Liturgia poprzez bogactwo znaków nadaje zewnętrzną oprawę treści, którą niesie związek małżeński. Znaki przypisane do tego obrzędu przez swoją naturę oddają pełnię łask, które Jezus Chrystus udziela dwojgu kochającym się ludziom, pragnących przypieczętować swój związek przed Bogiem. Kościelne prawo, które wynika

41 Tamże 29. 
z teologicznego rozumienia działania Boga w świecie wyznacza ramy, w których Kościół porusza się rozdzielając łaski, powierzone przez Jezusa Chrystusa. To prawo jest co jakiś czas uaktualniane, precyzowane w tych płaszczyznach, które w danym czasie wymagają uszczegółowienia ze względu na sytuację społeczną i świadomość ludzi, którzy wstępują w sakramentalne związki małżeńskie. Obrzędowość Kościoła Katolickiego jest wyrażeniem łask sakramentalnych - według najprostszej definicji widzialnym znakiem niewidzialnej łaski. Przebieg i znaki liturgiczne przypisane do obrzędów sakramentu małżeństwa są także dopowiedzeniem obrazowym, są obrzędami wyjaśniającymi istotę, cechy, skutki które są wpisane w teologiczne rozumienie katolickiego małżeństwa zawieranego pomiędzy kobietą i mężczyzną. Przykładem tych obrzędów są nie tylko słowa, które wypowiadają nupturienci, ale znaki, które dopełniają obrzęd sakramentalny. Do nich należy przewiązanie rąk stułą, czy też nałożenie obrączek.

Przeżycie i dogłębne zrozumienie sakramentu małżeństwa jest możliwe przez otwarcie się na żywego Boga, który przychodzi do człowieka w świętych znakach. Usposobienie wewnętrzne, żywe uczestnictwo w liturgii, wsłuchanie się w teksty, którymi Kościół zwraca się do Boga i nupturientów dają pełny ogląd na spojrzenie teologii katolickiej, a szczególnie dogmatyki i prawa kościelnego na rozumienie sakramentu małżeństwa jako nierozerwalnego związku mężczyzny i kobiety.

\section{The Rites of the Sacrament of Marriage - Implementation of the Code of Canon Law}

\section{Summary}

The liturgy of the Church is an expression of his life with Christ, it uses natural signs such as: wine, water, light, fire, smoke, oil, salt, and ash. It is through Christ, that they are given new meaning. This meaning is to glorify God and sanctify man. The sacramental ordinances are determined by ecclesiastical law which follows the nature and life of the Church. 
The ordinances of the Church, through the visible, direct us to the invisible. Behind what is visible there is no action or God's grace. These signs of God's presence are symbols, which St. Augustine calls the encounter between God and man in the world of signs and symbols, a Sacrament. The sacraments of the Church are graces given by God to man for his sanctification. In sacramental rites, the Church can change form, but never in essence and matter. The matter of the sacrament of marriage is between a woman and a man.

The rites of the sacrament of marriage, were announced in 1969, are used in Poland, however, it has been adapted to the new Code of Canon Law of 1983. Jesus instituted the sacrament of marriage. Marriage should be celebrated at Holy Mass and is characterized by unity and indissolubility. During the rites of the sacrament of marriage, the Church then asks what is the will of the person is for getting married. The couple then join their right hands and place the wedding rings on each other's ring finger. The effects of the sacrament of marriage, which express the Rites of the Sacrament of Marriage, are: marriage community, grace and family. The liturgy with the sacrament of marriage speaks of the sanctity of marriage through the beauty of its celebration.

Słowa klucze: Obrzędy sakramentu małżeństwa, Kodeks Prawa Kanonicznego, zgoda małżeńska, skutki sakramentu małżeństwa

Kay words: symbol, The Rites of the Sacrament of Marriage, The Code of Canon Law, marriage consent, effects of the sacrament of marriage

\section{Nota o autorze}

Ks. mgr lic. Ryszard Kilanowicz - doktorant nauk teologicznych Instytutu Liturgicznego im. bł. Michała Giedroycia na Wydziale Teologicznym Uniwersytetu Papieskiego Jana Pawła II w Krakowie, Duszpasterz Służby Liturgicznej Archidiecezji Krakowskiej. 